\title{
Pengaruh Kompensasi Finansial Terhadap Kinerja Karyawan Pada PT Penggadaian (Persero) Cabang Jambi
}

\author{
Fadil Iskandar \\ Fakultas Ekonomi Universitas Batanghari \\ Correspondence email: fdliskandar00@gmail.com
}

\begin{abstract}
This research aims to find out how implementation of the financial compensation and performance job of PT Penggadaian (Persero) Branch of Jambi. Next also to analyze implamentation and how the influence of financial compensation on performance job in PT Penggadaian (Persero) of Banch Jambi. This research uses descriptive method quantitative correlational research with the form that describes the relationship of independent variables with dependent variables. The research on the analysis tools using simple regression with hypothesis prove with statistical tests $t$. The results showed that a significant effect on performance financial compensation of performance job which are characterized by $t_{\text {count }}>t_{\text {table }}$ and Prog. sig $<\alpha(0.05)$. While the correlation value i.e. $64 \%$ of these mean that have relationship very closely between financial compensation variables with variable performance job.
\end{abstract}

Keywords: Financial Compensation, Performance Job

\section{Pendahuluan}

Manajemen sumber daya manusia merupakan salah satu bidang dari manajemen umum yang meliputi segisegi perencanaan, pengorganisasian, pelaksanaan, dan pengendalian.Proses ini terdapat dalam bidang /fungsi produksi, pemasaran, keuangan, ataupun kepegawaian.Sumberdaya manusiadiangggap semakin penting perannya dalam pencapaian tujuan perusahaan, karena kunci sukses sebuah perusahaan tidak berdasarkan dari modal yang tersedia serta keunggulan produk dari perusahaan tersebut melainkan sumber daya manusia yang dimiliki oleh perusahaan tersebut. Peran manusia dalam organisasi sebagai karyawan memegang peranan yang menentukan karena hidup matinya suatu organisasi semata-mata tergantung pada karyawannya, karena suatu organisasi semata-mata tergantung dari karyawannya itu sendiri. Keberhasilan suatu organisasi untuk mencapai tujuan dan sasarnnya serta kemampuannya menghadapi berbagai tantangan, baik bersifat internal maupun yang bersifat eksternal ditentukan oleh sumber daya manusia yang tepat.

Keberadaan sumber daya manusia di dalam suatu perusahaan memegang peranan sangat penting. Tenaga kerja memiliki potensi yang besar untuk menjalankan aktivitas perusahaan. Potensi setiap sumber daya manusia yang ada dalam perusahaan harus dapat dimanfaatkan dengan sebaik-baiknya sehingga mampu memberikan output optimal. Sumber daya manusia yang berkualitas dapat diperoleh melalui perekrutan yang selektif. Sistem perekrutan yang memperhatikan faktor kualitas yang diinginkan, ini tentu akan menjadi factor pendorong karyawannya agar dapat memaksimalkan dan cepat memahami tanggung jawab atas pekerjaannya. Tercapainya tujuan perusahaan tidak hanya tergantung pada peralatan modern, sarana dan prasarana yang lengkap, tetapi justru lebih tergantung pada manusia yang melaksanakan pekerjaan tersebut. Keberhasilan suatu organisasi sangat dipengaruhi oleh kinerja individu karyawannya. Setiap organisasi maupun perusahaan akan selalu berusaha untuk meningkatkan kinerja karyawan, dengan harapan apa yang menjadi tujuan perusahaan akan tercapai.

Dalam meningkatkan kinerja karyawannya perusahaan menempuh beberapa cara misalnya melalui pendidikan, pelatihan, pemberian kompensasi yang layak, menciptakan lingkungan kerja yang kondusif dan pemberian kompensasi finansial. Melalui proses-proses tersebut, karyawan diharapkan akan lebih memaksimalkan tanggung jawab atas pekerjaan mereka karena para karyawan telah terbekali oleh pendidikan dan pelatihan yang tentu berkaitan dengan implementasi kerja mereka. Sedangkan pemberian kompensasi, lingkungan kerja yang baik serta pemberian kompensasi finansial pada dasarnya adalah hak para karyawan dan merupakan kewajiban dari pihak perusahaan untuk mendukung kontribusi para karyawannya dalam rangka mencapai tujuan yang telah ditentukan. Pada penelitian ini variabel yang diamati adalah kompensasi finansial dan kinerja pegawai. Kompensasi menurut Hasibuan (2009) adalah semua pendapatan yang berbentuk uang, barang langsung atau tidak langsung yang diterima karyawan sebagai imbalan atas jasa yang diberikan kepada perusahaan. Tujuan pemberian kompensasi antara lain adalah sebagai ikatan kerja sama, kepuasan kerja, pengadaan efektif, kompensasi finansial, stabilitas karyawan, disiplin. Dan lain-lain. Kompensasi adalah penghargaan atau ganjaran pada para pekerja yang telah memberikan kontribusi dalam mewujudkan tujuannya, melalui kegiatan yang disebut bekerja.

Kompensasi juga merupakan penghargaan yang diberikan karyawan baik langsung maupun tidak langsung, financial maupun non financial yang adil kepada karyawan atas sumbangan mereka dalam mencapai tujuan organisasi, sehingga pemberian kompensasi sangat dibutuhkan oleh perusahaan manapun guna meningkatkan kinerja 
karyawannya. Adapun bentuk kompensasi financial adalah gaji, tunjangan, bonus,dan komisi. Sedangkan untuk kompensasi non-financial diantaranya pelatihan, wewenang dan tanggung jawab, penghargaan atas kinerja serta lingkungan kerja yang mendukung. Tidak hanya faktor pemberian kompensasi saja yang perlu diperhatikan oleh perusahaan guna meningkatkan kinerja karyawan, akan tetapi perusahaan Terpenuhinya kompensasi dan pemberian kompensasi finansial yang baik tentu saja akan meningkatkan produktivitas serta kinerja para karyawan. Arti kinerja atau performance adalah hasil kerja yang dapat dicapai oleh seseorang atau sekelompok orang dalam suatu organisasi sesuai dengan wewenang dan tanggung jawab masing-masing. Kinerja karyawanmerupakan suatu hal yang sangat penting dalam usaha organisasi untuk mencapaitujuannya. Oleh karena, itu salah satu cara terbaik untuk meningkatkan kapasitas kinerja karyawan adalah dengan menghubungkan kompensasi dengan perkembangan karyawan. Jika program kompensasi dirasakan adil dan kompetitif oleh karyawan, maka perusahaan akan lebih mudah untuk menarik karyawan yang potensial, mempertahankannya dan mekompensasi finansial karyawan agar lebih meningkatkan kinerjanya, sehingga produktivitas meningkat dan perusahaan mampu menghasilkan produk dengan harga yang kompetitif. Pada akhirnya, perusahaan bukan hanya unggul dalam persaingan, namun juga mampu mempertahankan kelangsungan hidupnya, bahkan mampu meningkatkan profitabilitas dan mengembangkan usahanya. Pada PT Pegadaian (Persero) Cabang Jambi dimana selama 5 tahun terakhir, pendapatan karyawan terus meningkat seiring dengan peningkatan jumlah karyawan. Sisi lain peningkatan tersebut tidak berbanding lurus dengan peningkatan kinerja karyawannya. Sehubungan dengan adanya fenomena tersebut maka pada penelitian ini bertujuan untuk menganalisis pengaruh dari kompensasi finansial terhadap kinerja pegawai PT Pegadaian (Persero) Cabang Jambi

\section{Landasan Teoritis \\ Kompensasi}

Pemberian kompensasi terhadap karyawan dalam sebuah perusahaan sangatlah penting, karena dengan adanya kompensasi tersebut karyawan akan merasa senang karena hasil kerja mereka mendapatkan imbalan atau balas jasa yang sesuai sehingga mereka lebih bersemangat dalam bekerja dan dapat meningkatkan kinerja karyawan. Menurut Sedarmayanti (2012) kompensasi adalah penghargaan atau ganjaran pada para pekerja yang telah memberikan kontribusi dalam mewujudkan tujuannya, melalui kegiatan yang disebut bekerja. Menurut Hasibuan (2009) kompensasi adalah semua pendapatan yang berbentuk uang, barang langsung atau tidak langsung yang diterima karyawan sebagai bentuk imbalan atau jasa yang diberikan oleh perusahaan. Dari beberapa pengertian diatas dapat disimpulkan bahwa kompensasi adalah penghargaan atau pendapatan yang berbentuk uang, barang langsung dan tidak langsung yang diterima karyawan sebagai imbalan atas jasa yang diberikan oleh perusahaan karena tenaga kerja tersebut telah memberikan sumbangan tenaga dan pikiran demi kemajuan perusahaan guna mencapai tujuan yang telah ditetapkan.

Kompensasi dapat dibagi atas kompensasi finansial dan kompensasi non finansial. Kompensasi finansial adalah kompensasi manajemen seperti upah dan gaji atau pay for performance, seperti insentif dan gain sharing. Menurut Nawawi (2015), kompensasi finansial adalah penghargaan berupa gaji atau upah, yang dibayar berdasarkan tenggang waktu yang tetap. Kompensasi non finansial meliputi semua imbalan finansial yang tidak tercakup dalam kompensasi langsung. Kompensasi non finansial menurut Nawawi (2015) adalah program penghargaan kepada karyawan sebagai bagian keuntungan perusahaan. Kompensasi non finansial adalah pemberian kompensasi yang tidak dikaitkan langsung dengan prestasi kerja karyawan. Kompensasi non finansial ini disebut juga kompensasi pelengkap karena berfungsi melengkapi kompensasi yang diterima karyawan melalui upah atau gaji. Jadi kompensasi non finansial merupakan balas jasa yang diberikan dalam bentuk penghargaan karyawan yang tidak dikaitkan dengan prestasi kerja sebagai bagian dari keuntungan perusahaan yang sesuai dengan kemampuan perusahaan.

Menurut Nawawi (2015) berdasarkan jenis-jenis kompensasi diatas maka indikator kompensasi finansial adalah : a) Gaji, b)Insentif. Faktor-faktor yang mempengaruhi tingkat gaji adalah sebagai berikut: 1)Tingkat Gaji yang Lazim Tingkat upah atau gaji tergantung pada ketersediaan tenaga kerja di pasar tenaga kerja. 2) Serikat Buruh, Serikat buruh bisa memaksa perusahaan memberikan upah atau gaji yang lebih besar dibandingkan hasil evaluasi jabatan. 3) Pemerintah, Penggajian harus disesuaikan dengan peraturan pemerintah seperti Upah Minimum Regional. 4) Kebijakan dan Strategi Penggajian, Kebijakan penggajian yang dipakai perusahaan, seperti mengusahakan gaji di atas harga pasar dalam upaya menghadapi persaingan, bisa menaikkan gaji di atas rata-rata harga pasar. 5) Faktor Internasional, Ketika perusahaan berkembang di segala penjuru dunia, penggajian harus diseuaikan dengan situasi negara yang bersangkutan. 6) Nilai yang Sebanding dan Pembayaran yang Sama, Ada kalanya pekerjaan yang berbeda, tetapi memiliki derajat yang sama mempunyai tingkat gaji yang berbeda. 7) Biaya dan Produktivitas, Mampu atau tidak mampunya perusahaan dalam mencapai keuntungan tertentu mengakibatkan kemampuan perusahaan membayar pekerja dan menarik investor menurun.

\section{Kinerja}

Tujuan utama manajemen sumber daya manusia adalah untuk meningkatkan kontribusi karyawan terhadap perusahaan dalam rangka mencapai produktivitas perusahaan yang bersangkutan. Dalam hal ini, keberhasilan berbagai 
aktivitas perusahaan sangat ditentukan oleh kinerja karyawan yang dimilikinya. Semakin baik tingkat kinerja karyawan yang dimiliki oleh perusahaan, semakin baik pula kinerja perusahaan tersebut. Menurut Rivai, (2014) menyatakan bahwa kinerja adalah hasil kerja yang dapat dicapai seseorang atau sekelompok orang dalam suatu organisasi dalam rangka mencapai tujuan organisasi dalam periode waktu tertentu. Menurut Dessler (2013) menyatakan bahwa kinerja adalah fungsi dari motivasi, kecakapan, dan persepsi peranan. Dari beberapa pendapat ahli diatas, penulis menyimpulkan bahwa kinerja karyawan merupakan hasil kerja yang dicapai oleh seorang karyawan, baik secara kualitas maupun kuantitas, sesuai dengan tugas dan perannya di dalam perusahaan untuk mencapai tujuan perusahaan. Dalam hal ini, kinerja yang efektif adalah mampu memenuhi sasaran dan standar kinerja yang terdapat dalam sebuah pekerjaan. Semakin baik seorang karyawan memenuhi sasaran dan standar yang terdapat dalam sebuah pekerjaan, berarti kinerjanya semakin optimal. Kinerja karyawan sangat menentukan keberhasilan perusahaan dalam merealisasikan berbagai tujuannya. Hal tersebut disebabkan karena karyawan merupakan orang yang melakukan perencanaan, pengorganisasian, pengarahan, serta melakukan pengendalian terhadap berbagai aktivitas perusahaan. Tanpa adanya karyawan yang kompeten, mustahil perusahaan dapat mencapai tujuannya secara efektif dan efisien. Untuk itu, setiap perusahaan perlu mengoptimalkan kinerja karyawan dalam rangka meningkatkan keunggulan kompetitif perusahaan.

\section{Metode}

Penelitian ini menggunakan pendekatan deskriftif kuantitatif dengan bentuk penelitian kolerasional. Penelitian ini dimaksudkan untuk mengetahui keterkaitan antara setiap variabel bebas dengan variabel terikat. Metode yang digunakan dalam penelitian ini adalah disesuaikan dengan judul penelitian yang ingin menguji hipotesis yang menerangkan hubungan variabel bebas dengan variabel terikat, serta membuat prediksi variable terikat atas setiap variabel bebas sehingga metode ini mencirikan penelitian survei dengan teknik korelasional. Penelitian ini dilakukan terhadap pegawai pada PT Penggadaian (Persero) Cabang Jambi. Objek penelitian ini ialah seluruh populasi pegawai pada PT Penggadaian (Persero) Cabang Jambi yang diteliti yang berjumlah 43 orang. Dan sampel yang digunakan dilakukan dengan menggunakan teknik sensus sampling, yakni penentuan sampel populasi sama dengan sampel. Penelitian menggunakan angket (kuisioner) dengan rincian pada variable kinerja pegawai berjumlah 8 item pertanyaan, variabel kompensasi finansial berjumlah 8 item pertanyaan. Prosedur pengumpulan data yaitu Responden diberikan waktu untuk mengisi kuisioner selama 30 sampai dengan 45 menit dan diperkenankan untuk mengklarifikasi pernyataan yang kurang jelas. Setelah selesai kuisioner dikumpulkan dan peneliti melakukan pengecekan terhadap kelengkapan dan kejelasan isian kuisioner untuk memastikan semua pernyataan telah terisi. Selanjutnya peneliti mengumpulkan kuisioner-kuisioner yang telah di isi responden ke dalam satu berkas. Namun apabila tidak semua responden mengisi pada saat itu juga, dikarenakan aktivitas responden yang tinggi sehingga beberapa kuisioner ada yang dibawa pulang untuk diambil dihari berikutnya.

Dalam penelitian untuk menganalisis data yang diperoleh secara deskriptif kualitatif. Analisis dilakukan berdasarkan teori yang mempunyai kaitan erat dengan aspek yang diteliti. Analisis deskriptif kualitatif merupakan penyesuiakan keadaan sebenarnya dan menggambarkan karakteristik peristiwa yang diamati serta menyimpulkan secara benar dan menyeluruh berdasarkan metode ilmiah dan menggunakan teori-teori yang dipelajari dan konsep yang relevan dalam permasalahan sebagai landasan berpijak dalam menganalisis. Untuk menganalisis permasalahan yang ada digunakan skala penelitian dengan menghitung frekuensi skor setiap item pertanyaan atau dengan skala linkert. Dalam arti bahwa perhitungan skor setiap komponen yang diteliti dengan mengalikan seluruh frekuensi data dengan nilai bobot. Untuk melihat bagaimana hubungan variabel independen dan variabel dependen, maka dilihat berdasarkan koefisien determinasi (R2). Yang mana koefisien determinasi merupakan angka yang menyatakan atau digunakan untuk mengetahui kontribusi atau sumbangan yang diberikan oleh sebuah variabel bebas terhadap variabel terikat. Secara sederhana koefisien determinasi dihitung dengan mengkuadratkan Koefisien Korelasi (r). Dilain sisi untuk melihat pengaruh dari variabel independen terhadap variabel dependen maka digunakan dalam bentuk pengujian statistik yakni uji t. Pada uji ini menyatakan apabila hasil t yang dihitung lebih besar dari t dalam tabel, maka dapat dinyatakan ada pengaruh variabel independen terhadap variabel dependen.

\section{Hasil}

Tabel 1

Indikator Kompensasi Finansial

\begin{tabular}{lrr}
\hline Indikator Kompensasi finansial & Rata-rata Skor & Keterangan \\
\hline Gaji & 170 & Baik \\
Insentif & 177 & Baik \\
Rata-rata & 230,5 & Baik \\
\hline
\end{tabular}

Sumber: data olahan 
Skor variabel independent (Kompensasi finansial) dimana rata-rata skornya sebesar 230,5 kategori Tinggi, ini menunjukan bahwa responden merasa mempunyai kompensasi finansial yang tinggi dalam pelaksanaan tugas-tugas yang diberikan oleh atasannya. Pada pernyataan responden indikator insentif menunjukan skor tertinggi, yakni skor sebesar 177 dari variable kompensasi finansial yakni skor sebesar 228 pada pegawai PT Penggadaian (Persero) Cabang Jambi. Maknanya bahwa responden kompensasi finansial pegawai pada PT Penggadaian (Persero) Cabang Jambi berkategori tinggi sehingga giat dan sungguh-sungguh dalam melaksanakan pekerjaan yang diberikan. Pada indikator ekstrinsik jawaban mempunyai skor tertinggi yakni, kesesuaian imbalan yang diterima seimbang dengan tanggung jawab yang diberikan. Sedangkan dilain pihak hak atas pegawai yang didapatkannya sesuai dengan tanggung jawab dan wewenang yang dibebankan oleh atasannya. Sehingga dapat membuat kompensasi finansial yang tinggi bagi pegawai untuk melaksanakan semua pekerjaan yang ada.

Tabel 2

Indikator Kompensasi Finansial

\begin{tabular}{lcc}
\hline Indikator Kinerja & Rata-rata Skor & Keterangan \\
\hline Kualitas Kerja & 178 & Baik \\
inisiatif & 170 & Baik \\
Ketepatan waktu & 170 & Baik \\
Kemampuan & 182 & Baik \\
Komunikasi & 170 & Baik \\
Rata-rata & 175 & Baik \\
\hline
\end{tabular}

Sumber: data olahan

Variabel kinerja pegawai dimana rata-rata skornya sebesar 226,8 kategori baik ini menunjukan bahwa kinerja pegawai pada PT Penggadaian (Persero) Cabang Jambi tinggi. Pada indikator mutu kerja, pernyataan responden dalam melakukan pekerjaan selalu hati-hati agar tidak membuat kesalahan dalam mengerjakan. Dimana pada pernyataan ini menunjukan skor tertinggi dari beberapa indikator dari variable kinerja pegawai yakni sebesar 235. Ini dapat disimpulkan bahwa dalam melakukan pekerjaan, pegawai pada PT Penggadaian (Persero) Cabang Jambi selalu diselesaikan dengan sedikit kesalahan. Sehingga pekerjaan diselesaikan dengan efektif dan efisien.

Tabel 3 diperoleh hitungan uji $t_{\text {hitung }}$ untuk kompensasi finansial sebesar 5,566 lebih besar dari $t_{\text {tabel }}(8,537>$ 1,683). Dilain sisi nilai signifikansi yang lebih kecil dari 0,05 yaitu $0,004<0,05$, serta nilai koefisien regresi dari kompensasi finansial $(\mathrm{X})$ bertanda $(+)$. Maka dapat disimpulkan bahwa Rkompensasi finansial berpengaruh signifikan terhadap kinerja pegawai dan berhubungan positif terhadap kinerja pegawai.

Tabel 3

Regresi Linear Sederhana

\begin{tabular}{|c|c|c|c|c|c|c|c|}
\hline \multirow{2}{*}{\multicolumn{2}{|c|}{ Model }} & \multicolumn{2}{|c|}{ Unstandardized Coefficients } & \multirow{2}{*}{\multicolumn{2}{|c|}{$\begin{array}{c}\text { Standardized Coefficients } \\
\text { Beta } \\
\end{array}$}} & \multirow[b]{2}{*}{$\mathrm{t}$} & \multirow[b]{2}{*}{ Sig. } \\
\hline & & $\mathrm{B}$ & Std. Error & & & & \\
\hline \multirow[t]{2}{*}{1} & (Constant) & 3,271 & 1,873 & & 1,747 & ,088 & 3,271 \\
\hline & KFINANSIAL & ,856 & 101 & ,800 & 8,537 & ,000 & 856 \\
\hline
\end{tabular}

Sumber: data olahan

Tabel 4

Korelasi dan Determinasi

\begin{tabular}{|l|r|r|r|r|}
\hline Model & R & R Square & Adjusted R Square & Std. Error of the Estimate \\
\hline 1 & $8^{2}, 800^{\mathrm{a}}$ &, 640 &, 631 & 2,68113 \\
\hline
\end{tabular}

Sumber: data olahan

Tabel 4 juga dapat dilihat nilai korelasi (r) yakni sebesar 0,80 atau 80\%, maknanya bahwa hubungan variabel independen dalam hal ini adalah kompensasi finansial terhadap variabel dependen (kinerja pegawai) sangat erat. Nilai koefisien determinasi $\left(\mathrm{R}^{2}\right)$ sebesar 0,64 atau 64\% variasi kinerja karyawan yang bisa dijelaskan oleh variasi variabel independen yaitu kompensasi finansial. Sedangkan sisanya 36\% dijelaskan oleh faktor lain diluar penelitian.

\section{Simpulan}

Kuesioner responden skor tertinggi dari indikator pada variabel independen (kompensasi finansial) adalah inisiatif skor sebesar 177 kategori tinggi. Dimana indikator mengerjakan pekerjaan giat dan sungguh-sungguh dalam melaksanakan pekerjaan yang diberikan oleh atasan. Dan pemberian hak pegawai sesuai dengan tanggung jawab yang dibebankan oleh atasannya, sehingga ini membuat tingginya kompensasi finansial pegawai dalam melaksanakan pekerjaan. Pada variabel Kinerja Pegawai, indikator yang tertinggi skornya yakni sebesar 182 kategori Baik adalah mutu kerja dan kualitas kerja. Dimana pada indikator ini penyelesaian pekerjaan yang tepat waktu dan tekun dan 
sungguh-sungguh dalam melaksanakan pekerjaan yang diberikan. Sedangkan dari uji t disimpulkan bahwa kompensasi finansial berpengaruh signifikan terhadap kinerja pegawai pada PT Penggadaian (Persero) Cabang Jambi. Hal ini ditandai dengan $t_{\text {hitung }}>t_{\text {tabel, }}$, serta pro.sig $<\alpha$

\section{Daftar Pustaka}

Flippo, Edin, Dessler, 2013, Human Recources Management, International Edition, Mc Grawhill Inc, Singapore Hasibuan, Malayu SP. 2009. Manajemen Sumber Daya Manusia. Penerbit Bumi Aksara. Jakarta Nawawi, 2015, Manajemen Sumber Daya Manusia, Edisi keenam, PT Erlangga, Jakarta.

Sedarmayanti. 2012, Sumber Daya Manusia dan Produktivitas Kerja, CV. Mandar Maju. Bandung Veithzal, Rivai 2014, Kepemimpinan dan Perilaku Organisasi, PT.Rajagrafindo Persada, Jakarta 